\title{
CLIMATE CONTROL ON WINTER WAVE ACTIVITY IN THE NORTHEAST ATLANTIC AND IMPACTS ON BEACH EROSION AND RECOVERY ALONG THE WEST COAST OF EUROPE
}

\author{
BRUNO CASTELLE ${ }^{1}$, GUILLAUME DODET ${ }^{2}$, GERD MASSELINK ${ }^{3}$, TIM \\ SCOTT $^{3}$
}

1. CNRS/Univ. Bordeaux, UMR EPOC, Allée Geoffroy Saint-Hilaire, France. bruno.castelle@u-bordeaux.fr

2. IFREMER, Univ. Brest, CNRS, IRD, Laboratoire d'Océanographie Physique et Spatiale, IUEM, Brest, France. Guillaume.dodet@ifremer.fr

3. Coastal Processes Research Group, School of Biological and Marine Sciences, Plymouth University, United Kingdom.gerd.masselink@plymouth.ac.uk; timothy.scott@plymouth.ac.uk

\begin{abstract}
The west coast of Europe is exposed to high-energy winter waves generated in the North Atlantic Ocean by low pressure systems traveling eastward. The present study builds on recent research on atmospheric and ocean wave climate in the North East Atlantic over the last 70 years using numerical weather and wave hindcast, in-situ sea-level pressure measurements, and beach response from a unique dataset of decadal beach morphological changes along the west coast of Europe. Interannual to decadal variability of winter wave activity in the North East Atlantic is strongly affected by the North Atlantic Oscillation (NAO) and the West Europe Pressure Anomaly (WEPA). It is found that extreme winter-mean wave heights become more frequent and variability increases, resulting in extreme winters such as that of 2013/14. We show that the recovery signature is site-specific and multi-annual, and that interannual variability of both erosion and recovery is well correlated with WEPA and NAO.
\end{abstract}

\section{Introduction}

Large-scale patterns of atmospheric and oceanic variability over interannual and longer timescales can have a profound influence on temperature, rainfall or storm tracks and intensity (Wang and Schimel, 2003). Coastal hazards are also strongly affected by large-scale climate patterns with changes in extreme wave climate having the potential to cause dramatic change in the equilibrium state of beaches (e.g., Barnard et al., 2015; Masselink et al., 2016). As climate is changing, it is therefore increasingly important to link extreme wave energy arriving locally at the coast to large-scale oceanic and atmospheric variability (Camus et al., 2014) and how this drives trends and interannual variability in shoreline change (Dodet et al., 2019).

The west coast of Europe comprises a wide range of low-lying and/or populated regions. It is exposed to high-energy winter waves generated in the North Atlantic Ocean by extratropical storms traveling eastward, with maximum track density found between about $45^{\circ} \mathrm{N}$ in the West Atlantic to about $70^{\circ} \mathrm{N}$ in the Norwegian Sea (Zappa et al., 2018). During the 2013/2014 
winter, the combination of a very intense polar vortex and unusually strong North Atlantic jet stream caused a succession of deep low pressure systems to cross the Atlantic (Davies, 2015) and reach western European coastlines. The combination of high cyclone frequency and above-average cyclone intensity resulted in exceptional storminess. At the coast, considerable impacts were reported across the entire European Atlantic seaboard, down to Morocco (e.g., Castelle et al., 2015; Blaise et al., 2015; Autret et al., 2016; Masselink al., 2016; Burvingt et al., 2018; Cox et al., 2018). This stimulated new research over the last four years linking up storminess in the North Atlantic, climate variability, and resulting beach response and recovery.

The present study builds on recent research (Masselink et al., 2016; Castelle et al., 2017, 2018; Dodet et al., 2019) on atmospheric and ocean wave climate in the North East Atlantic over the last 70 years using numerical weather and wave hindcast, in-situ sea-level pressure measurements, and beach response from a unique dataset of decadal beach morphological changes along the west coast of Europe.

\section{Data and methods}

\section{Atmospheric and ocean wave climate: winter means and trends}

The data and method used are described in detail in Castelle et al. (2017). In short, 6-hourly sea-level-pressure (SLP) and 10-m wind $\left(\vec{u}_{10}\right)$ fields $\left(2.5^{\circ} \times 2.5^{\circ}\right)$ were downloaded/obtained from the National Centers for Environmental Prediction (NCEP) / National Center for Atmospheric Research reanalysis project (Kalnay et al., 1996), while EOF-based monthly teleconnection indices NAO, EA, and SCAND were downloaded from the National Oceanic and Atmospheric Administration (NOAA) Climate Prediction Center (www.cpc.ncep.noaa.gov). The spectral wave model WAVEWATCH III V4.18 (Tolman, 2014) was implemented on a $0.5^{\circ}$ resolution grid covering the North Atlantic Ocean $\left(80^{\circ}-0^{\circ} \mathrm{W} ; 0^{\circ}-70^{\circ} \mathrm{N}\right)$ forced with the 6-hourly wind fields $\vec{u}_{10}$. This modelling strategy was extensively validated in Masselink et al. (2016).

A smaller-scale, high-resolution model was used to simulate the wave conditions close to the breaking point at the five study sites described hereabove. For this purpose we used a WAVEWATCH III hindcast (19922017) implemented on an unstructured grid with a resolution increasing from $10 \mathrm{~km}$ offshore to $200 \mathrm{~m}$ in the coastal region, and extending from north of Spain to south of Ireland (Ardhuin et al., 2012; Boudière et al., 2013). Hereafter, we address winter (December, January, February, and March - DJFM) averages of wave and atmospheric variability from 1949 to 2017 (67 winters). Wintermean (December to March, 1949-2017) significant wave height $H_{s}$ is shown in Fig. 1a. 


\section{Beach data}

Five beaches along the Atlantic coast of Europe (see their locations in Fig. 1a) were surveyed on a monthly basis for more than 10 years, which is the most complete series of beach profiles in western Europe. Of note, two representative beach profiles were analyzed separately for Slapton Sands, as this site displays a strong alongshore variability in beach profile evolution owing to rotation. Morphological characteristics as well as information on survey methods can be found in Masselink et al. (2016) and Dodet et al. (2019). To address beach system change, shoreline position and beach volume above mean sea level $(V)$ were computed for each site, which include the dune system at Vougot, Porsmilin and Truc Vert.

\section{Results}

\section{Winter wave climate variability and trends}

Winter-mean (DJFM, 1949-2017) significant wave height $H_{s}$ is shown in Fig. 1a. Results show that interannual to decadal variability of winter wave activity in the North East Atlantic in the northern latitudes, north of $50^{\circ} \mathrm{N}$, is strongly affected by the North Atlantic Oscillation (NAO, Fig. 1b), while the recently developed West Europe Pressure Anomaly (WEPA, Castelle et al., 2017) index outscores all the conventional climate indices, including the NAO, in explaining winter wave height variability along the west coast of Europe, from UK $\left(52^{\circ} \mathrm{N}\right)$ to Portugal $\left(35^{\circ} \mathrm{N}\right)$, and even further south along the northwest coast of Africa (Fig. 1c)

Using an algorithm that objectively searches for the optimal SLP-based climate index, the WEPA index was defined in Castelle et al. (2017) as the normalized sea level pressure (SLP) gradient between the stations Valentia (Ireland) and Santa Cruz de Tenerife (Canary Islands, Spain). The WEPA positive phase reflects an intensified and southward-shifted latitudinal SLP gradient across the east Atlantic, driving severe storms that funnel highenergy waves toward the west coast of Europe southward of $52^{\circ} \mathrm{N}$ (Castelle et al., 2017; Malagon Santos et al., 2017). 

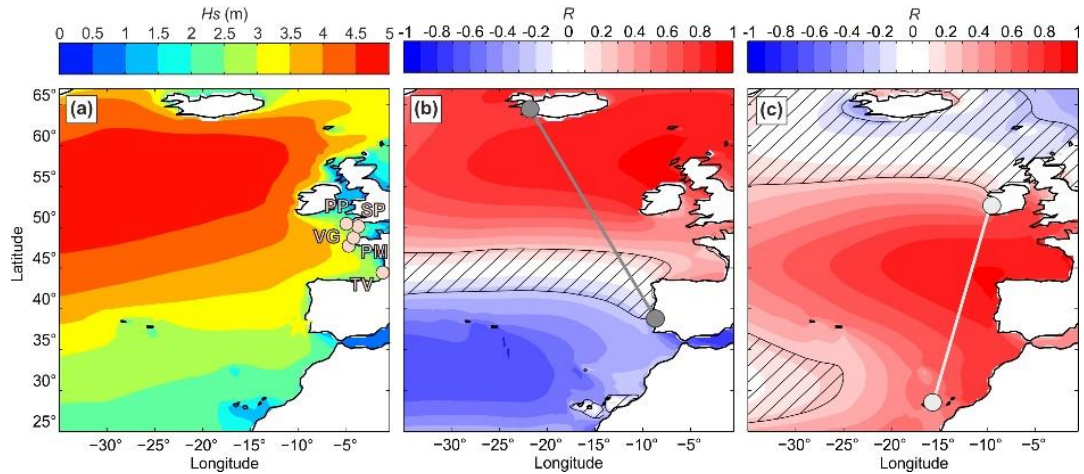

Fig. 1. (a) Winter-mean (December to March, 1949-2017) $H_{s}$ with locations (circles) of beach study sites Perranporth (PP), Slapton Sands (SP), Vougot (VG), Porsmilin (PM), Truc Vert (TV); Spatial correlation of the winter-mean $H s$ against the (DJFM) winter-averaged (b) NAO and (c) WEPA indices. The North Atlantic Oscillation (NAO) and West Europe Pressure Anomaly (WEPA) indices defined as the normalized sea level pressure difference measured between two stations are indicated by the dark and light gray circles in panels. The hatched zones are the areas where correlations are not significant at the $95 \%$ confidence level.

NAO and WEPA are found to explain extreme winter wave conditions in the North-East Atlantic, in the Bay of Biscay and in the Celtic Seas (Dodet et al., 2010; Castelle et al., 2017). The extreme winter 2013/2014, which was characterized by a striking pattern of temporal and spatial extreme storm clustering with the highest winter average wave height since at least 1948 (Masselink et al., 2016), was associated with an average positive NAO, but with the highest WEPA over the period (WEPA index of +2.66). During this winter, the latitudinal atmospheric dipole of anomaly resembled the NAO+ pattern shifted $15^{\circ}$ southward together with a substantial longitudinal anomaly driving increased W-NW winds around $45^{\circ} \mathrm{N}$ (Fig. 2a). This generated larger waves along the entire coast of Europe, down to northwest Africa, with anomaly peaking at $+1.62 \mathrm{~m}$ at approximately $50^{\circ} \mathrm{N}$ (Fig. $2 \mathrm{~b}$ ).
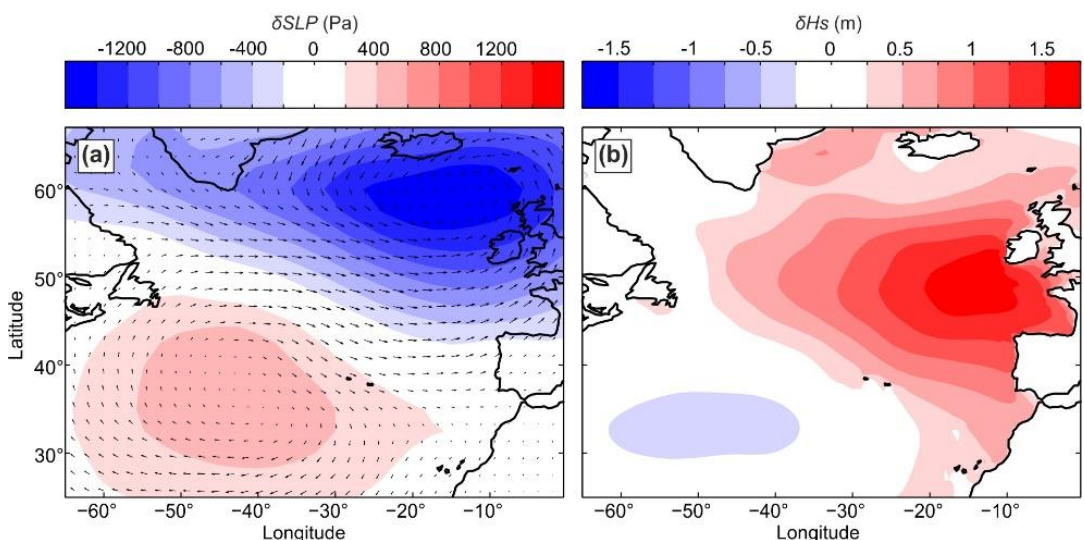

Fig. 2. Atmospheric and wave height expression of the winter of 2013/2014 showing the highest WEPA. (a) winter-mean SLP anomaly with superimposed $\vec{u}_{10}$ field and (b) winter-mean Hs anomaly. 
Figure 3 shows the spatial map of linear trends in winter-mean $H_{s}$ (Fig. 3a) and winter-mean $H_{s}$ interannual variability (Fig. $3 b$ ). For the latter, the time evolution of the 10-year moving standard deviation of local winter-averaged $H_{s}$ was linearly regressed. Results show a large increase in winter average $H_{s}$ over the last 69 years exceeding $10 \mathrm{~mm} /$ year offshore of Scotland and Ireland, that is, an increase by more than $0.7 \mathrm{~m}$ over the study period. The rate of increase in winter average $H_{s}$ decreases southward to approximately 5 and 1 $\mathrm{mm} /$ year along the French and Portuguese coasts, respectively, although the trend is not statistically significant at the $95 \%$ level along the Spanish and Portuguese coasts. Importantly, removing the outstanding 2013/2014 does not alter these rates off the Irish coast, but substantially decreases those further south.

The patterns of linear trends in winter $H_{s}$ interannual variability (Fig $3 \mathrm{~b}$ ) are quite different from those computed directly from the winter Hs (Fig3a). Although the maximum increase is located along the Irish coast $(+1.2-$ $1.4 \%$ year), most of the west coast of Europe also shows a large increase (+0.6-1\%/year). This large increase along all the west coast of Europe is largely due to the increased range in normalized winter $H_{s}$ since the early 1990s (Castelle et al., 2018). Both NAO and WEPA show the same rate of increase in interannual variability of $+0.5 \% /$ year (not shown).

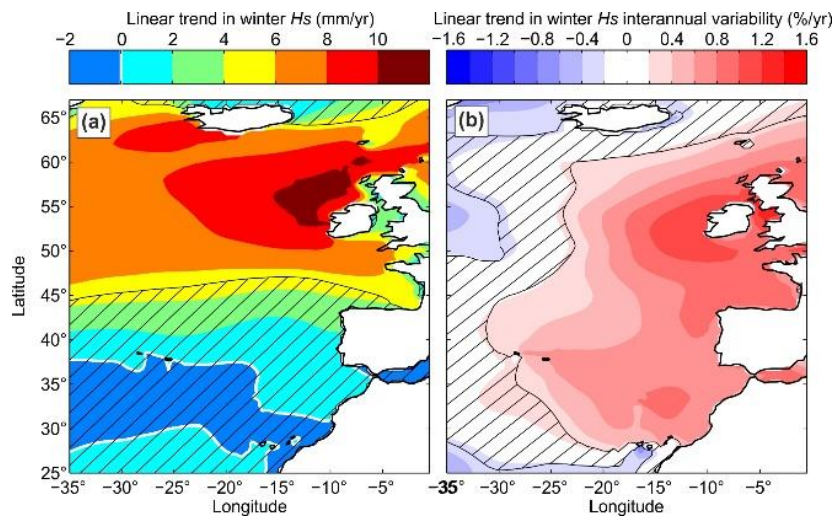

Fig. 3. Linear trend of (a) winter-mean (1949-2017) $H_{s}$ and (b) winter-mean (1949-2017) Hs interannual variability in percent/year. The hatched zones are areas where trends and correlations are not significant at the $95 \%$ confidence level.

\section{Beach response}

Fig. 4 shows the time evolution of beach volume and dune foot position at the study sites, with outstanding storm erosion impacts during the 2013/2014 winter leaving the majority of the sites in their most depleted state since measurements began. The most exposed sites (Perranporth and Truc Vert) lost in excess of $200 \mathrm{~m}^{3} / \mathrm{m}$ from the intertidal beach and dune system, and such storm response was observed to be typical of most exposed beaches 
along the coast of SW England and France. Contrasting responses occurred at the more sheltered sites such as Porsmilin and Vougot. At Slapton Sands, the middle profile (SP10) experienced a sediment loss of $100 \mathrm{~m}^{3} / \mathrm{m}$, whereas accretion of a similar amount occurred at the north profile (SP18) owing to unprecedented beach rotation (Masselink et al., 2015). Fig. 4 shows that the recovery signature is site-specific and multi-annual, with one studied beach fully recovered after 2 years, and the others only partially recovered after 4 years. Results also show that beaches recover during the spring-summerautumn period at modest and relatively steady rates (not much inter-annual variability). However, it is the energetic winter conditions that primarily control the time it takes for beaches to recover from extreme erosion as energetic winter conditions stall the recovery process whereas moderate winter conditions accelerate it. Additional efforts (not shown, see Dodet et al., 2019) show that on exposed beaches, equilibrium models (e.g., Yates et al., 2009; Davidson et al., 2013; Splinter et al., 2014) show significant skills in reproducing the post-storm recovery and thus can be used to investigate the recovery process in more detail, while at other sites more complex shoreline models (Vitousek et al., 2017; Robinet et al., 2018) should be used. 

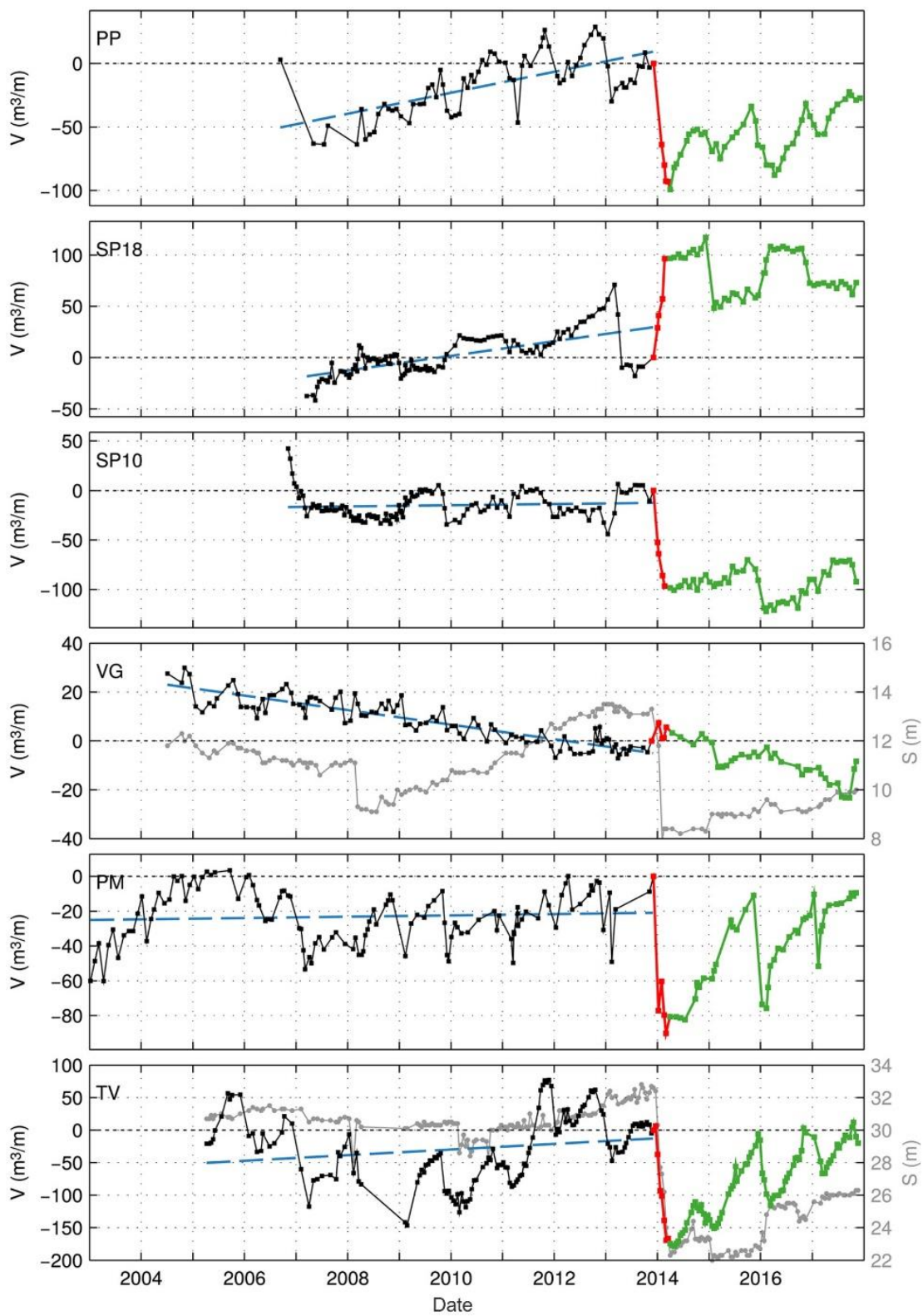

Fig. 4. Time series of beach volume at the five study sites (with two profiles shown for Slapton Sands), with the beach volume set to zero on 1 December 2013. The dashed blue line represents the long-term trend over the period prior to the 2013/2014 winter, the red line represents the 2013/2014 winter response and the green line represents the recovery period. For Vougot and Truc Vert the evolution of the location of the dune foot (grey line) is also shown. 


\section{Conclusion}

The winter-mean wave height, variability, and periodicity all increased significantly in the northeast Atlantic over the last seven decades. These changes in wave height primarily are significantly correlated with two climate indices - the North Atlantic Oscillation (NAO) and the West Europe Pressure Anomaly (WEPA) - which reflect changes in atmospheric circulation in the North Atlantic. These various modes of variability resulted, in recent years, in more high-WEPA winters with extreme winter-mean $H_{s}$ situations along the west coast of Europe, with the winter of 2013/2014 standing out. During this outstanding winter, extensive beach and dune erosion occurred along exposed open-coast sites due to offshore sediment transport. More sheltered sites experienced less erosion and one of the sites even experienced accretion due to beach rotation induced by alongshore sediment transport. The recovery of beaches from this outstanding winter was site-specific and multi-annual, with one studied beach fully recovered after 2 years, and the others only partially recovered after 4 years. During the recovery phase, winter waves primarily control the timescales of beach recovery, as energetic winter conditions stall the recovery process whereas moderate winter conditions accelerate it. This inter-annual variability is well correlated with climate indices. With high-energy winter becoming more common during the next decades if the trend in both winter-mean wave height and interannual variability continues, predicting WEPA and NAO a few months ahead is crucial to anticipate coastal hazards, which is of interest for coastal and climate communities.

\section{Acknowledgements}

This work was financially supported by SONO (ANR-17-CE01-0014) and CHIPO (ANR-14-ASTR-0004) projects of the Agence Nationale de la Recherche (ANR). GD is supported by ESA under Sea State CCI project. GM and TS were funded by the NERC BLUE-coast project (NE/N015525/1). The French sites Vougot, Porsmilin and Truc Vert are monitoring sites of the Service National d'Observation (SNO) DYNALIT labelled by CNRS-INSU and part of the French Research Infrastructure ILICO, with Truc Vert receiving additional monitoring financial support from Observatoire de la Côte Aquitaine and Observatoire Aquitain des Sciences de l'Univers (OASU). The authors would like to thank the very many colleagues, postdocs, field technicians and $\mathrm{PhD}$ students involved in the beach profile data collection as well as Serge Suanez, France Floc'h and Derek Jackson for sharing some beach profile data that were used in the beach response analysis. We acknowledge NCEP/NCAR and Ifremer institutes for providing the wind field reanalysis and the wave hindcast, respectively.

\section{References}

Ardhuin, F., Roland, A., Dumas, F., Bennis, A.-C., Sentchev, A., Forget, P., 
Wolf, J., Girard, F., Osuna, P., and Benoit, M. (2012). Numerical wave modeling in conditions with strong currents: Dissipation, refraction, and relative wind, Journal of Physical Oceanography, 42(12), 2101-2120.

Autret, R., Dodet, G., Fichaut, B., Suanez, S., David, L., Leckler, F., Ardhuin, F., Ammann, J., Grandjean, P., Allemand, P., and Filipot, J.-F. (2016). A comprehensive hydro-geomorphic study of cliff-top storm deposits on Banneg Island during winter 2013-2014, Marine Geology, 382, 37-55.

Barnard, P., Short, A., Harley, M., Splinter, K.D., Vitousek, S., Turner, I.L., Allan, J., Banno, M., Bryan, K., Doria, A., Hansen, J., Kato, S., Kuriyama, Y., Randall-Goodwin, E., Ruggiero, P., Walker, I., and Heathfield, D. (2015). Coastal vulnerability across the Pacific dominated by El Nino/Southern Oscillation, Nat. Geosci., 8(10), 801-807, doi:10.1038/ngeo2539.

Blaise, E., Suanez, S., Stephan, P., Fichaut, B., David, L., Cuq, V., Autret, R., Houron, J., Rouan, M., Floc'h, F., Ardhuin, F., Cancouet, R., Davidson, R., Costa, S., and Delacourt, C. (2015). Review of winter storms 20132014 on shoreline retreat dynamic on Brittany coast, Geomorphologie: Relief, Processus, Environnement, 21, 267-292.

Boudière, E., Maisondieu, C., Ardhuin, F., Accensi, M., Pineau-Guillou, L., and Lepesqueur, J. (2013). A suitable metocean hindcast database for the design of marine energy converters, International Journal of Marine Energy, 3-4, e40-e52.

Burvingt, O., Masselink, G., Scott, T., Davidson, M., and Russell, P. (2018). Climate forcing of regionally-coherent extreme storm impact and recovery on embayed beaches, Marine Geology, 401, 112-128.

Camus, P., Menendez, M., Mendez, F.J., Izaguirre, C., Espejo, A., Canovas, V., Perez, J., Rueda, A., Losada, I.J., and Medina, R. (2014). A weathertype statistical downscaling framework for ocean wave climate, $J$. Geophys. Res. Oceans, 119, 7389-7405, doi:10.1002/2014JC010141.

Castelle, B., Marieu, V., Bujan, S., Splinter, K.D., Robinet, A., Sénéchal, N., and Ferreira, S. (2015). Impact of the winter 2013-2014 series of severe Western Europe storms on a double-barred sandy coast: Beach and dune erosion and megacusp embayments, Geomorphology, 238, 135-148.

Castelle, B., Dodet, G., Masselink, G., and Scott, T. (2017). A new climate index controlling winter wave activity along the Atlantic coast of Europe: The West Europe Pressure Anomaly, Geophysical Research Letters, 44, 1384-1392. https://doi.org/10.1002/2016GL072379. 
Castelle, B., Dodet, G., Masselink, G., and Scott, T. (2018). Increased wintermean wave height, variability, and periodicity in the Northeast Atlantic over 1949-2017, Geophysical Research Letters, 45(8), 3586-3596.

Cox, R., Jahn, K.L., Watkins, O.G., and Cox, P. (2018). Extraordinary transport by storm waves (west of Ireland, winter 2013-2014), and criteria for analyzing coastal boulder deposits, Earth-Science Reviews, $177,623-636$.

Davidson, M., Splinter, K.D., and Turner, I.L. (2013). A simple equilibrium model for predicting shoreline change, Coastal Engineering, 73, 191202.

Davies, H. C. (2015). Weather chains during the 2013/2014 winter and their significance for seasonal prediction, Nat. Geosci., 8, 833-837.

Dodet, G., Bertin, X., and Taborda, R. (2010). Wave climate variability in the North-East Atlantic Ocean over the last six decades. Ocean Modelling, $31,120-131$

Dodet, G., Castelle, B., Masselink, G., Scott, T., Davidson, M., Floc'h, F., Jackson, D., and Suanez, S. (2019). Beach recovery from extreme storm activity during the 2013/14 winter along the Atlantic coast of Europe. Earth Surface Processes and Landforms, 44(1), 393-401, doi:10.1002/esp.4500.

Kalnay, E., Kanamitsu, M., Kistler, R., Collins, W., Deaven, D., Gandin, L., et al. (1996). The NCEP/NCAR 40-year reanalysis project, Bulletin of the American Meteorological Society, 77(3), 437-471.

Malagon Santos, V., Haigh, I. D., and Thomas, W. (2017). Spatial and temporal clustering analysis of extreme wave events around the UK coastline, Journal of Marine Science and Engineering, 5(3), 28. https://doi.org/10.3390/jmse5030028.

Masselink, G., Castelle, B., Scott, T., Dodet, G., Suanez, S., Jackson, D., and Floc'h, F. (2016a), Extreme wave activity during 2013/2014 winter and morphological impacts along the Atlantic coast of Europe, Geophys. Res. Lett., 43, 2135-2143, doi:10.1002/2015GL067492.

Robinet, A., Idier, D., Castelle, B., and Marieu, V. (2018). A reducedcomplexity shoreline change model combining longshore and crossshore processes: the LX-Shore model, Environmental Modelling \& Software, 109, 1-16.

Splinter, K.D., Turner, I.L., Davidson, M.A., Barnard, P., Castelle, B., and 
Oltman-Shay, J. (2014). A generalized equilibrium model for predicting daily to interannual shoreline response, Journal of Geophysical Research: Earth Surface, 119(9), 1936-1958.

Tolman, H. L. (2014). "User manual and system documentation of WAVEWATCH III version 4.18", NOAA/NWS/NCEP/MMAB Technical Note 316, p. 194.

Vitousek, S., Barnard, P.L., Limber, P., Erikson, L., and Cole, B. (2017). A model integrating longshore and cross-shore processes for predicting long-term shoreline response to climate change, Journal of Geophysical Research: Earth Surface, 122, 782-806.

Wang, G., and D. Schimel (2003). Climate change, climate modes, and climate impacts, Annu. Rev. Environ. Resour., 28(1), 1-28.

Yates, M.L., Guza, R.T., and O’Reilly, W.C. (2009). Equilibrium shoreline response: Observations and modeling, Journal of Geophysical Research: Oceans, 114(C9): C09014.

Zappa, G., Shaffrey, L.C., and Hodges, K.I. (2013). The Ability of CMIP5 Models to Simulate North Atlantic Extratropical Cyclones, J. Climate, 26, 5379-5396. 